\title{
An Analysis of Doctoral Dissertations Based on the Sex of Supervisors: A Case of Sociology Departments in Turkey
}

\author{
A. Güler and Z. Kurnaz
}

\begin{abstract}
This study examines doctoral dissertations based on sex of supervisors year periods and universities in which have a sociology $\mathrm{PhD}$ program in Turkey and also it determines whether there are any significant differences according to those variables. Currently, Turkey has 169 universities that 63 of those have been admitting students for undergraduate program of sociology departments. In addition, 25 universities have doctoral program at sociology. However, doctoral dissertations have been conducted only in 14 universities among them. Totally 513 doctoral dissertations were found which were conducted between 1950 and 2012. In this study only 493 doctoral dissertations, out of 513, were analyzed. The qualitative and quantitative context analyze has been applied from the socio-historical critique point of view by using MAXQDA. Consequently, this study indicates that there is gender-related differentiation of doctoral dissertations' supervisors based on years and universities that doctoral dissertations were conducted in departments of sociology.
\end{abstract}

Index Terms-Higher education, sociology departments, doctoral dissertations, sex of supervisors.

\section{INTRODUCTION}

It is usually accepted that a doctoral dissertation has a significant mission for making original and substantial contribution to advanced knowledge in an academic discipline. In this respect, doctorate studies have been based on independent and new work conducting an original research. A doctoral program therefore entails that candidate should complete a research required for acceptance of a dissertation [1]. Doctoral candidate, in turn, should be accepted as potential scholars who will have an important role in national research systems in the near future [2], [3], [4].

Graduate education is the main part of higher education of Turkey, with more than one hundred and twenty four thousands students enrolled in graduate programs. Approximately 27 percent of all are graduate students pursuing doctoral degrees and out of those numbers, women accounted for 43 percent of all doctoral degrees [5].

The doctoral supervisor is accepted to be one of the most important persons with whom doctoral students will develop a relationship during their doctoral degree programs [6]. Supervisors play crucial role in the doctoral experience and in achieving faster progression and lower attrition rates among students [7], [8]. A supervisor not only advises but provides access to helpful and useful resources and identifies

Manuscript received May 10, 2013; revised July 8, 2013.

Abdurrahim Güler and Zeynep Kurnaz are with the Department of Sociology, Hacettepe University, Ankara, Turkey (e-mail: gulerrahim@gmail.com; navavar@windowslive.com). opportunities to develop a student's career by involving them in active research projects. Accordingly, supervisor is who helps doctorate candidates and gets them enrolled in the appropriate classes and gained valuable knowledge, contributes to their socialization and the quality of their doctoral experiences, evaluates their progress and in general shepherds them, provides participating in research projects as well; they also helps candidates to become part of the academic community [9].

The primary aim of this study is to describe profiles of doctoral dissertations which were conducted in sociology departments based on sex of supervisors from 1950 to 2012. Another aim is to identify whether there is any differentiation of doctoral supervisors over years and based on university at which dissertations were conducted.

\section{LITERATURE REVIEW}

Scholars who are generally placed at universities produce new technology and information, because the new knowledge was resulted conducting well-organized researches and experiments. At the universities, researches were needed to be done by doctorate candidates in order to get their titles and diplomas. Doctorate candidates therefore need being advised by a skilled and wise person to contribute their academic studies. In academic community, this person is a supervisor who plays a vital, at the same time, trivial role in the life of doctorate candidates and his/her contribution to field. Merriam et al. [10] identify that supervising relationships between supervisors and doctoral students have a special effect on students' academic life, careers, intellectual development. Supervising is a process where supervisor and doctorate candidate work together and facilitate professional success. Supervisors also are guiding and showing candidates what to do. Daloz [11] states "they lead us along the journey of our lives. We trust them because they have been there before. They embody our hopes, cast light on the way ahead, interpret arcane signs, warn us of lurking dangers, and point out unexpected delights along the way." Then again supervisors are important for the way in which doctorate candidates on for general support and encouragement [12]. Levinson [13] extends further it and points out that the most important function of a supervisor is to support and facilitate the realization of the dreams.

Supervisor serving basic and important functions at which transfer formal scientific knowledge and skills [14] in doctorate candidate's life and help share his/her doctorate student's emotional load at appropriate times [15]. Succeeding the transition depends most critically on whom they choose as their supervisor, because this choice is almost 
as important as whom they select as their spouse. It is not merely that an adviser provides equipment and supplies, access to assistantships, and vital letters of recommendation. Supervisors provide immediate and constructive feedback regarding a student's attempts to understand nature [16]. Supervisor who supervises doctoral students' professional development and formalizes their disciplinary identities during academic socialization experiences [17] is not easy to find due to supervising characterized as activities and interactions that may be related to work, skill development, and social or emotional sides of the supervisor [18].

It is assumed that the rate of supervisors who supervised doctorate candidates is significantly different and women's rate is not the same as men's. It means sex of supervisor is crucial and has impacts on evaluation of candidates of academic experiences [19]. It is noteworthy that female supervisors were just as likely as their male colleagues to favor the male students. The fact that discrimination was independent of their sex, scientific discipline, and age suggests that it is likely unintentional, generated from widespread cultural [20]. On the other hand, Anderson and Devanna [21] found virtually no sex bias in the supervising of graduate student.

\section{Methodology ${ }^{1}$}

In this study, it has been analyzed doctoral dissertations in which were conducted in sociology department at universities of Turkey. First of all, the data base of the Council of Higher Education has been scanned to achieve universities' information. Accordingly, from 1933 to present totally 169 universities have been established. ${ }^{2}$ In order to specify which university has sociology department, we looked into the Guidebook of the Higher Education Programs and Quotas for 2012 in which prepared by Measuring, Selection and Placing Center (ÖSYM). The only 63 of 169 universities have been admitting students for undergraduate program of sociology departments. ${ }^{3}$ Furthermore, just the 25 of those 63 universities have a doctoral program in sociology and doctoral dissertation has been conducted only in 14 universities of all them. ${ }^{4}$

The data of this study were collected from May, 2012 to Apr, 2013. The data bases of National Dissertation Center at the Council of Higher Education and dissertation center of universities have been investigated and achieved 513 doctoral dissertations conducted in sociology departments between 1950 and 2012. In this study only 493 doctoral dissertations, out of 513, were analyzed. 20 of those dissertations were excluded from this study by reason of the fact that 5 of them have not been found their supervisor's

${ }^{1}$ The methodology was used in named 'Doctoral Theses in the Context of Globalization and Modernization: A Case of Turkey' paper at International Journal Arts \& Science (IJAS) Conference (Vienna, 2013) which was a part of this study.

2 The latest inquiry was made in March 22, 2013 over http://www.yok.gov.tr/web/guest/universitelerimiz web page. Numbers gradually increase in Turkey due to demanding qualified employees.

${ }^{3}$ The numbers are taken from the Guidebook of the Higher Education Programs and Quotas for 2012.

${ }^{4}$ The latest data was obtained in March 30, 2013 from web page of institutes of social science. information and 15 of them have two supervisors.

The qualitative and quantitative context analyze has been applied from the socio-historical critique point of view by using MAXQDA, which is professional software for qualitative and mixed methods for data analysis.

Those dissertations in which were reached as full texts of them from the data base of National Dissertation Centre at the Council of Higher Education have been put together around a project of MAXQDA. Other dissertations, which not reaching them as full texts have been collected by searching on library catalogs. Afterwards, those data have been combined in the same project with creating new files. Consequently, after creating a data base of MAXQDA file for dissertations in which were conducted between 1950 and 2012; then data were coded based on years, universities and sex of supervisors. It has been followed Strauss' coding paradigm [22]. The data at the beginning are coded by open coding, and then axial and selective coding. The coding, in case codes are not decided, is discussed by authors and then arrived at a consensus and later codes have been finalized in its form.

\section{FINDINGS}

When looking at sexes of supervisors of doctoral dissertations which were conducted in sociology department in Turkey over years, it is seen that there is no any supervisor who was woman until 1980. In 30-years period, there were only 10 doctoral dissertations that were conducted in sociology departments. The reason in here is structural problem because until 1980s most universities were newly-established and few of them had sociology departments. In despite of the findings, woman supervisors are gradually increasing since 1990 (Table I). Birsen Gökçe was the first woman scholar who supervised thesis that completed in sociology departments in 1983. The rates of theses that supervised by men consist of approximately $69 \%$ (339) and remainders by women as 31\% (154). The number of women Scholars who supervised is nearly half of men scholars who did same thing until 2010, although the rates of women had increased between 2010 and 2012 years period. If taking this period as 3 years, others are 10 years, into consideration; it can draw an inference that women scholars will increase in number in after days.

TABLE I: SEX OF SUPERVISORS BASED ON YEAR PERIODS

\begin{tabular}{|c|c|c|c|c|c|c|c|c|}
\hline \multirow{3}{*}{$\begin{array}{l}\text { Sexes of } \\
\text { Supervisors }\end{array}$} & \multicolumn{7}{|c|}{ Year Periods of Doctoral Dissertations } & \multirow{3}{*}{ Total } \\
\hline & 1950 & 1960 & 1970 & 1980 & 1990 & 2000 & 2010 & \\
\hline & 1959 & 1969 & 1979 & 1989 & 1999 & 2009 & 2012 & \\
\hline Man & 5 & 2 & 5 & 9 & 98 & 158 & 62 & 339 \\
\hline Woman & & & & 4 & 36 & 72 & 42 & 154 \\
\hline Total & 5 & 2 & 5 & 13 & 134 & 230 & 104 & 493 \\
\hline
\end{tabular}

Table II includes examined the numbers of doctoral dissertations (Column II), the number of scholars who supervised dissertations (Column III), the number of dissertations per supervisors (Column IV) and total number of doctoral dissertations which were conducted in sociology departments at the 14 universities of Turkey. And also it shows the distributions of current scholars based on their sex 
and universities where they work at (Column V).

In column where current rate of scholars working at the sociology departments in turkey shows the rate of current scholars who are working at 14 universities where doctoral dissertation produced. Those data are collected from web page of those universities. According to those data, particularly at Cumhuriyet University, İnönü University, İstanbul University, Sakarya University, Firat University and Ege University men scholars are more in numbers than women. At the same time, at those universities men supervisors also dominate dissertations. Men scholars are supervised 196 of 216 doctoral dissertations. At Ankara University, Hacettepe University, Middle East Technical University, all are in Ankara, and Mimar Sinan Fine Art University, in Istanbul, women scholars in number are higher than all others. The inference in here, women scholars mostly work at central universities which are located in metropolitan cities which are Ankara, İstanbul, İzmir.

There is a strange situation happening in Istanbul because Istanbul University is a first university at which established in Turkey and also second university that has sociology department in the world.5 Even Istanbul University has great boasting history; it does not give equal chance to men and women. It becomes a tradition for Istanbul University. This tradition seems to be continuing when we look at sexes of supervisors of dissertations. Because men supervised 58 dissertations but women supervised only 6 dissertations at Istanbul University. The number of doctoral dissertations that supervised per different men scholars is 4.8 and for women scholars, it is only 2 dissertations. At the present time, there is no any differentiation regard to distribution of sexes of scholars who work at İstanbul University (see, column V in table II). It is almost ten times and inequalities between sexes are clear. In turn, Istanbul University keeps the tradition and inequality going.

The findings indicate that Ankara and Hacettepe University are the most producer of the dissertations that supervised by women scholars regard to distribution of sexes of supervisors (see table II). The scholars of 20 out of 27 are women at Ankara University and 65 out of 109 are also women at Hacettepe University. On the other hand, there are some universities at which no one women supervised dissertations, such as Cumhuriyet University, Sakarya University and Ege University. In those universities there is no any doctoral dissertation in which is made by women. In particular, doctoral dissertations that were conducted at İstanbul University, Furat University, Ege University, and Middle East Technical University (METU) are mostly SUPERVISED BY MEN SCHOLARS.

The highest rate of women scholars who currently work at a university is Hacettepe University, nevertheless the number of dissertation per women scholars who supervised dissertations are less than men. The number of dissertations per supervisor is 7.1 for men and 5.9 for women at Hacettepe University. Similarly, METU is another university at which women scholars who work at are doubled men scholars, but

\footnotetext{
${ }^{5}$ Chair of Sociology Department of İstanbul University, Baykan Sezer says: "Our sociology department is one of the oldest departments with Durkheim's in France. At he same time, it is the first sociology department that established outside of western World" [23], [24].
}

the same situation is applicable for it, for men scholars 4.8 and for women 2.3 dissertations. Even though men who supervised doctoral dissertations are higher than women supervisors from past to present day, nowadays women scholars who work at METU are remarkable when compare with past situation (See and compare with column II and column V, Table II).

TABLE II: DISSERTATIONS AND SCHOLARS BY UNIVERSITIES

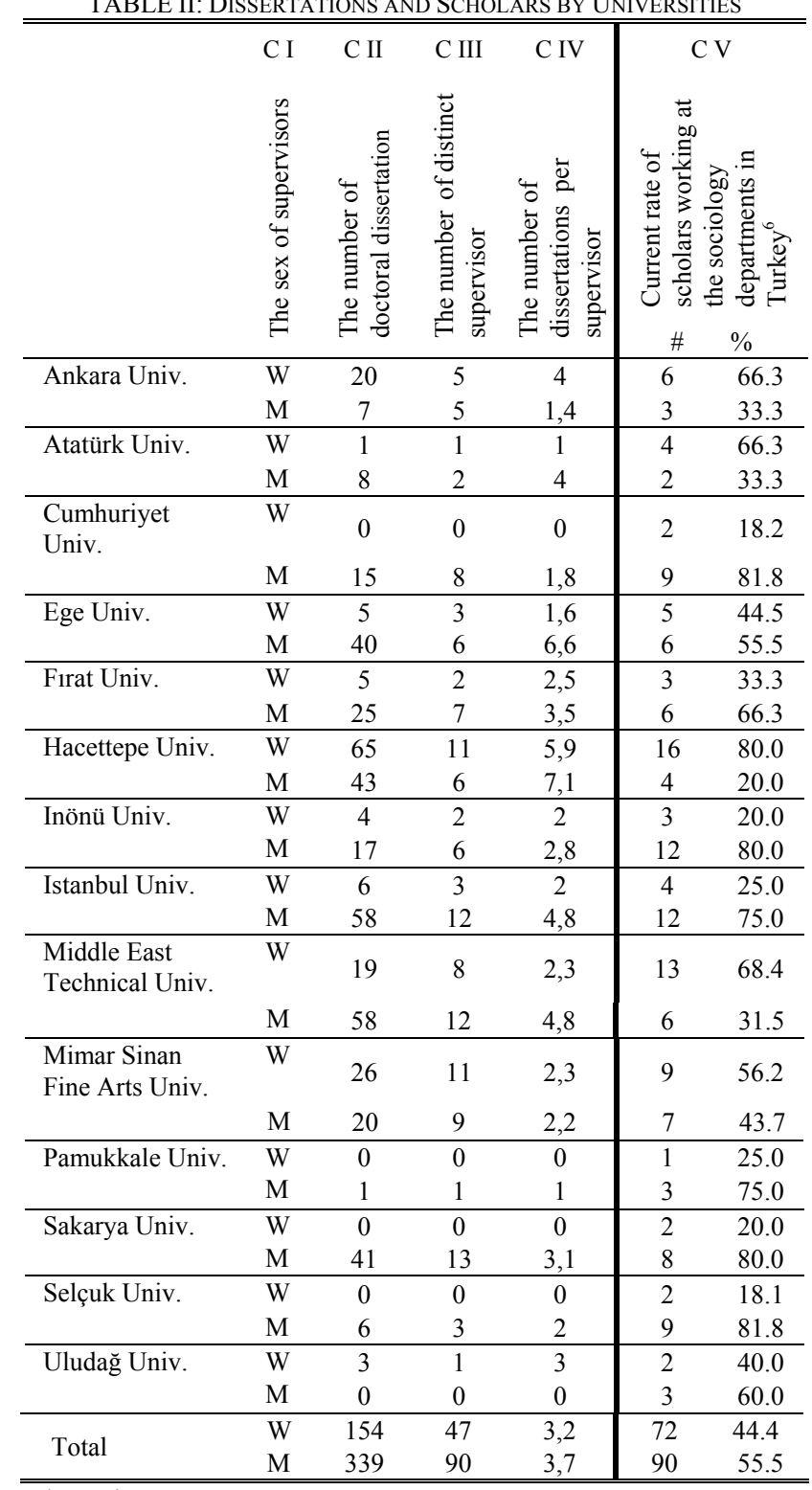

*C: column, W: woman, $\mathrm{M}:$ man

By contrast, the highest rate of women scholars who supervised dissertations is Ankara University. In there the rate is 74 percent for women supervisors. In Ankara University, the number of dissertations per supervisors is 4 and this is only one university that women dominate dissertations as supervisors. Mimar Sinan Fine Art University is another university that the number of

\footnotetext{
${ }^{6}$ Those data were obtained in May 8, 2013 and cover scholars who hold the title of professors, associate professors, assistant professors and lecturers in the sociology departments of universities. The distribution of research assistants was excluded. Due to not possible to reach all scholars who have worked at in sociology departments at the universities of Turkey, only the current data were given.
} 
dissertations per supervisors for women are higher as 2.3. In Cumhuriyet and Sakarya Universities totally produced 56 dissertations with 21 different supervisors, but nonetheless no one woman scholars supervised in those both universities.

Totally, 513 doctoral dissertations were conducted in sociology departments at universities of Turkey and only 493 of all doctoral dissertations were analyzed. 137 different scholars are supervised those dissertations and approximately two third (90/137) of them are men scholars. Additionally, the sexes of supervisors of doctoral dissertations are mostly men. 339 doctoral dissertations are supervised by men and 154 of them supervised by women. It can emphasize that the sexes of supervisors of doctoral dissertations and current scholars who work at universities are going to hand in hand. When the sex differentiations penetrate scholars, it also impacts sexes of doctoral candidates.

The numbers of current scholars who work at universities are in favor of men with 90 scholars. In addition to the numbers of distinct supervisors, the rate of women scholars is only 34.3 percent. The only 31.2 percent of dissertations are supervised by women scholars. It can point out that the rate of scholars who work at universities does not make any difference, generally in all cases the rate of women who supervised are less than men.

In Table III, it is given current distribution of sexes of scholars who are teaching and supervising for dissertations in sociology departments in which have a sociology doctoral program in Turkey

TABLE III: CURRENT NUMBER OF SCHOLARS WORKING AT THE SOCIOLOGY DEPARTMENTS IN TURKEY (IT COVERS ONLY 14 UNIVERSITIES IN WHICH

\begin{tabular}{lccc}
\multicolumn{4}{c}{ HAVE A SOCIOLOGY PHD PROGRAM) } \\
\hline \hline & Woman & Man & Total \\
\hline Prof. Dr. & 16 & 27 & 43 \\
Assoc. Prof. & 16 & 23 & 39 \\
Assist. Prof. & 32 & 36 & 68 \\
Inst. Dr. & 8 & 4 & 12 \\
\hline Total & 72 & 90 & 162 \\
\hline \hline
\end{tabular}

Data are gained as identified above from official web page of related sociology departments for 2013. In 14 universities that have doctoral programs, in total 162 scholars are working at. 90 scholars are men and others are women. The distribution of sexes of professors and associate professors are widely different and men double women scholars in numbers. To this respect, even though the distribution of sexes of assistant professors is almost the same and equally spread in sociology department. It should keep in mind that data cover only information of 14 universities and scholars who work at those universities. It does not represent all 63 universities that have sociology departments; because we analyze only 14 universities that have doctoral program in sociology. When think of those 63 universities, the distribution of scholars based on their sex is going to be change in the future.

\section{CONCLUSION AND DISCUSSION}

In developing world there are still discriminations between man and woman against women but discrimination is diminishing. Academic arena is place where gender equality should be but unfortunately those discriminations obviously were seen at universities where center of equality are. When looking at the universities of Turkey where sociology departments have and doctoral dissertations were conducted, it was seen that distribution of scholars based on their sexes are against women. Even if taking institutionalized universities into account, the rates of men scholars nearly doubled women's rate and in some universities there is no any dissertation in which were supervised by women scholars. Discriminations are not only related to women scholars who worked at universities, besides depending on who supervised doctorate dissertations. Considering the number and the rate of women scholars are close to men at some universities, women conspicuously supervised dissertations less than men. In recent years, women scholars who are working at and supervising increase in number but still not enough for a developing and getting more democratized Turkey. To sum, although our study's scope only cover 14 universities and cannot generalize for all university of Turkey, it draws a picture of the situation of Turkey's university.

\section{REFERENCES}

[1] S. Parry, Disciplines and Doctorates, Springer, Netherlands, 2007, pp. $15-23$.

[2] H. Aittola, "Doctoral education and doctoral theses-Changing, assessment, practices," in Cultural Perspectives on Higher Education, J. Välimaa and O.-H. Ylijoki, Eds. Springer, Netherlands, 2008, pp. 161-177.

[3] C. Halse and S. Mowbray, "The impact of the doctorate," Studies in Higher Education, vol. 36, no. 5, pp. 513-525, August 2011.

[4] E. Mathieu and F. Adams, "Doctoral study programmers in Europe," Fresenius' Journal of Analytical Chemistry, vol. 357, no. 2, pp. 215-220, January 1997.

[5] ÖSYM. summary table of number of students. [Online]. Available: http://www.osym.gov.tr/dosya/1-60395/h/1ogrencisayozettablosu.pdf

[6] L. L. Baird, "Helping graduate students: A graduate adviser's view," New Directions for Student Services, A. S. Pruitt-Logan and P. D. Isaac, Eds. San Francisco, CA: Jossey-Bass, vol. 1995, no. 72, pp. 25-32, Winter 1995.

[7] A. Lee, "How are doctoral students supervised? Concepts of doctoral research supervision," Studies in Higher Education, vol. 33, no. 3, pp. 267-281, June 2008.

[8] P. G. Altbach, "The United States: Present realities and future trends," in Studies on Higher Education: Doctoral Studies and Qualifications in Europe and the United States, J. Sadlak, Ed. Bucharest, UNESCO-CEPES, 2004, pp. 259-275.

[9] W. Lyons, D. Scroggins, and P. B. Rule, "The mentor in graduate education," Studies in Higher Education, 1990, vol. 15, no. 3, pp. 277-285.

[10] S. B. Merriam, T. K. Thomas, and C. P. Zeph, "Mentoring in Higher Education: What We Know Now," The Review of Higher Education, vol. 11, no. 2, pp. 199-210, Winter 1987.

[11] L. A. Daloz, Effective Teaching and Mentoring: Realizing the Transformational Power of Adult Learning Experiences, Jossey-Bass Inc Publication, San Francisco, 1986.

[12] M. T. Nettles and C. M. Millett, Three Magic Letters: Getting to Ph.D, Baltimore, Johns Hopkins Press, 2006.

[13] D. J. Levinson, The Seasons of a Man's Life, Alfred A. Knopf, New York, 1978.

[14] B. F. Reskin, “Academic sponsorship and scientists' careers. sociology of education," Sociology of Education, vol. 52, no. 3, pp. 129-146, July 1979.

[15] E. Alleman, J. Cochran, J. Doverspike, and I. Newman, "Enriching Mentoring Relationships," The Personnel and Guidance Journal, vol. 62, no. pp. 329-332, December 2011.

[16] M. L. Dermer, "Enhancing Personal Satisfaction, Professional Success, and the Quality of Science-Providing Frank Advice," Journal of College Science Teaching, vol. 21, pp. 200-201, February 1992.

[17] M. Gasman, A. Hirschfield, and J. Vultaggio, "Difficult yet rewarding: The experiences of African American graduate students in education at 
an ivy league institution," Journal of Diversity in Higher Education, vol. 1, no. 2, pp. 126-138, June 2008.

[18] M. N. Davidson and L. F. Johnson, "Mentoring in the preparation of graduate researchers of color," Review of Educational Research, vol. 71, no. 4, pp. 549-574, Winter 2001.

[19] W. Lyons, D. Scroggins, and P. B. Rule, "The mentor in graduate education," Studies in Higher Education, vol. 15, no. 3, pp. 277-285, 1990.

[20] C. A. M. Racusin. Science faculty's subtle gender biases favor male students. [Online]. http://www.pnas.org/content/early/2012/09/14/1211286109.full.pdf

[21] C. Anderson and M. A. Devenna, "Mentor: can they help women to get ahead?" Career Development Activities, vol. 2, no. 2, pp. 5-8, 1981.

[22] A. L. Strauss, Qualitative Analysis for Social Scientists, Cambridge University Press, Cambridge, New York, 1987.

[23] B. Sezer, Türkiye'de Sosyolojinin 75. Yill, 75 Anniversary of Sociology in Turkey, İstanbul Universitesi Edebiyat Fakültesi Basımevi, İstanbul, 1989, pp. 5.

[24] S. Sağlam, Ziya Gökalp, Türkiye'de Sosyoloji I: İsimler ve Eserler içinde, In Sociology in Turkey I: Names and Publications, M. Çağatay Özdemir, Ed. Phoenix Press, Ankara, 2008, pp. 216.

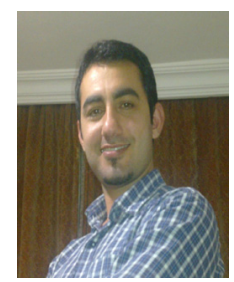

Abdurrahim Güler was born in Gercüş/Batman-Turkey in October 27, 1986. He went to high school in same city then for my undergraduation. He studied at Fatih University in major of Sociology. Now he is doing his integrated $\mathrm{PhD}$. on sociology in institute of social sciences at Hacettepe University in Turkey. He spent 3 years studying on his integrated $\mathrm{PhD}$. And now he is preparing his thesis proposal. His research interests are refugees, asylum seekers, migrants, race and ethnicity, and multiculturalism.

He worked for Ağrı İbrahim Ceçen University from September to May, 2011. And now he works for Hacettepe University in Ankara, Turkey as Research Assistance.

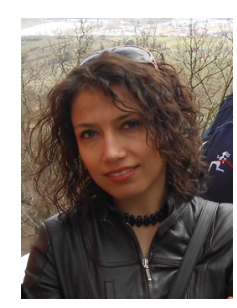

Zeynep Kurnaz was born in Ankara-Turkey in Jun. 06, 1981. She studied at the Ankara University in the Department of Sociology for undergraduation. She got a master degree at the Department of History of the Hacettepe University in Ankara, Turkey on 2010. Her master thesis subject was "We-Consciousness" and the Ways of Gaining Visibility of Ethnic Groups in the Ottoman Empire. She currently is doing her $\mathrm{PhD}$. studies in the Sociology Department of the Hacettepe University in Ankara, Turkey while working in the same place as a research assistant. She is formulating a research project concerned with fear in Turkey.

She worked for the Karabük University from September to May, 2011. Now she works for Hacettepe University in Ankara, Turkey as Research Assistance. 